\title{
ПОДГОТОВКА БУДУЩЕГО УЧИТЕЛЯ НАЧАЛЬНЫХ КЛАССОВ К СОЗДАНИЮ КОНСПЕКТА УРОКА
}

\author{
Т. Б. Кропочева, Т. А. Налимова, М. В. Синева \\ Новокузнецкий институт (филиал) Кемеровского государственного университета, \\ Новокузнеик
}

Анализ научно-методической литературы позволил сделать вывод о расширении научных публикаций по проблеме подготовки будущего учителя начальных классов. Вместе с тем многие вопросы подготовки учителя к организации и проведению урока в соответствии с федеральными государственными стандартами начального общего образования являются дискуссионными и выявляют недостатки в качественной методической подготовке будущего учителя. Выявленные недостатки определили проблему исследования: каким образом необходимо осуществлять подготовку будущего учителя начальных классов к выполнению конспекта урока? Теоретическая значимость исследования состоит в конкретизации сущности и содержания подготовки будущего учителя к выполнению конспекта урока; в теоретическом обосновании методики результативной подготовки учителя к выполнению конспекта урока. Практическая значимость заключается в разработке методики организации самостоятельной работы студента в аспекте его подготовки к выполнению конспекта урока. Обеспечение качественной подготовки специалистов требует не только опоры на государственные образовательные стандарты, определяющие минимум требований к содержанию и уровню подготовки выпускников, но и более эффективного управления процессом овладения студентами содержанием образования, в том числе самостоятельной работой, которая сегодня составляет существенную долю по сравнению с аудиторными занятиями. Подготовка будущего учителя начальных классов к выполнению конспекта урока определяется как процесс формирования у студента системы знаний (типология, целеполагание, структурирование урока), умений (умение выделять тип, цель, дидактические и учебные задачи, универсальные учебные действия, структуру урока, методы обучения), личностных и профессиональных качеств (творческое воображение, педагогическая импровизация), обеспечивающих результативность организации современного урока.

Ключевые слова: подготовка будущего учителя, требования к современному уроку в начальной школе, цель, задачи, типология, структура и конспект урока.

Основной целью высшего педагогического образования является качественная подготовка будущего учителя. Этой цели должна быть подчинена вся система педагогического образования. Обеспечение качественной подготовки специалистов требует не только опоры на государственные образовательные стандарты, определяющие минимум требований к содержанию и уровню подготовки выпускников, но и более эффективного управления процессом овладения содержанием образования, в том числе самостоятельной работой студентов, которая сегодня составляет в высшем учебном заведении существенную долю по сравнению с аудиторными занятиями. 
Самостоятельная работа студентов занимает важное место в процессе обучения любой дисциплине. В высшей школе, где меняется сам характер процесса обучения (по сравнению со средней школой), где студенты должны слушать лекции и уметь записывать их содержание, где им приходится выполнять различного рода научные исследования, где отсутствует ежедневный контроль со стороны преподавателей, умение самостоятельно работать имеет решающее значение. Преподаватель вуза организует познавательную деятельность будущих учителей, а студент самостоятельно осуществляет познание. При этом формируются прочные знания, поскольку они добываются студентами через преодоление трудностей; развиваются важнейшие качества личности современного учителя: самостоятельность, активность, инициативность мышления, творческий подход к работе, подлинный познавательный интерес к предмету.

Самостоятельную работу по методике обучения любому предмету начального образования (дисциплине «Окружающий мир», русскому языку, литературному чтению, математике и пр.) можно разделить на три вида:

1. Аудиторная самостоятельная работа (выполнение практических заданий во время лабораторного практикума).

2. Внеаудиторная самостоятельная работа (выполнение домашних заданий, проведение педагогических наблюдений и анализа уроков в школе).

3. Тестовые контрольные работы.

В статье описан опыт авторов по организации внеаудиторной самостоятельной работы студентов в рамках решения одной из важнейших проблем курса методики обучения, связанной с подготовкой учителя к уроку в современной начальной школе.

Анализ научно-методической литературы позволил сделать вывод о расширении научных публикаций по проблеме подготовки будущего учителя начальных классов. Вместе с тем многие вопросы подготовки учителя к организации и проведению урока в соответствии с федеральными государственными образовательными стандартами начального общго образования (ФГОС НОО) являются дискуссионными и вызывают недостатки в качественной методической подготовке будущего учителя, в частности, не уделяется должного внимания закономерностям развития профессиональной компетентности будущего учителя по организации современного урока; недостаточно используется образовательный потенциал педагогического вуза в подготовке будущего учителя к реализации системно-деятельностного подхода; не в полной мере изучены вопросы типологии, целеполагания, структурирования урока в начальной школе.

Педагогический вуз призван готовить учителя начальных классов как воспитателя и как специалиста по ряду учебных предметов начальной школы, поэтому изучение любой методической дисциплины должно строиться на предметных знаниях, полученных студентами в курсах педагогики, психологии, возрастной физиологии и предметов специальных циклов (естественно-географического и общественно-исторического в курсе «Методика обучения предмету „Окружающий мир“ в начальном общем образовании», филологического и культуроведческого - в курсе «Методика обучения русскому языку и литературе в начальной общем образовании» и т. д.). Теоретические предметные знания преломляются в курсе методической дисциплины, опора на них в значительной степени облегчает решение задач формирования методических знаний и умений на практических занятиях и во время педагогической практики, поэтому необходимо организовать межпредметное повторение к занятиям, что облегчает формирование частнометодических понятий.

Рассмотрим на нескольких примерах из курса «Методика обучения русскому языку и литературе в начальном общем образовании», как теоретические знания помогают студен- 
ту в рамках внеаудиторной самостоятельной работы подготовиться к моделированию методических ситуаций возможных уроков. С этой целью целесообразно предложить будущим учителям включиться в решение методических задач, например:

1. Подготовьте вопросы для анализа философской сказки С. Козлова «Ежик в тумане». Определите круг литературоведческих понятий, которые могут стать средством анализа этого произведения. Составьте алгоритм-памятку для учителя «Я провожу урок чтения философской сказки для детей».

2. Составьте рекомендательный список произведений современной детской литературы (не менее шести авторов) для учащихся 3-4-х классов. Объясните свой выбор.

3. Перед вами перечислены типы заданий, которые используются при изучении морфемного состава слова. Подберите к каждому из них пример конкретного упражнения: 1) объяснение значения ряда однокоренных слов через «главное» родственное слово; 2) замена описания понятия одним однокоренным словом; 3) «выращивание» слов из одного корня; 4) объяснение детских словообразовательных ошибок, их исправление; 5) конструирование слов по определенной модели; 6) наблюдение за использованием слов с конкретными морфемами в текстах.

4. Составьте вариант вводного слова учителя, открывающего изучение грамматической темы. Как объяснить детям необходимость изучения грамматики?

Решение подобных методических задач, на наш взгляд, позволит подготовить студентов к продумыванию каждого эпизода будущего урока, будет способствовать формированию творческого педагогического мышления.

Далее покажем, как можно сочетать теоретические вопросы и практические задания по проблеме подготовки будущего учителя к созданию конспекта урока в процессе организации внеаудиторной самостоятельной работы по дисциплине «Методика обучения предмету „Окружающий мир“».

Теоретические вопросы по рассматриваемой проблеме представлены пунктами 1 и 2, а практические задания показаны в пункте 3.

Пункт 1. Опорные понятия: 1) из курса педагогики к занятию необходимо повторить требования к современному уроку, его структуре и типологии; 2) из курса методики обучения предмету «Окружающий мир» необходимо повторить следующий материал: типы и виды уроков окружающего мира; цель урока, дидактические и учебные задачи, структура каждого типа урока; методы и приемы обучения окружающему миру и их классификация.

Пункт 2. Основное содержание изучаемого материала. Каждый урок по предмету «Окружающий мир» должен вооружать учащихся соответствующими понятиями и представлениями, умениями и навыками, на основе которых решаются задачи развития и воспитания учащихся начальных классов. Исходя из возрастных и индивидуальных особенностей младших школьников, на уроке должны применяться разнообразные методы и приемы, позволяющие знакомить учащихся непосредственно с предметами и явлениями окружающего мира, их взаимосвязями и законами проявления на Земле. Нельзя ограничиваться на уроке окружающего мира только словесными или только практическими методами, все методы должны применяться системно и способствовать развитию естественно-научных или обществоведческих понятий и общедидактических или специальных умений.

Урок окружающего мира должен быть хорошо оборудован системой наглядных пособий и приборов, при этом желательно использовать натуральные и изобразительные пособия, лабораторное и экскурсионное оборудование, а не только информационные средства обучения, которые в современной школе превалируют в виде презентаций.

В соответствии со специальными принципами обучения окружающему миру (краеведческим, экологическим, фенологическим) на уроках окружающего мира широко применя- 
ется местный природный материал, изучаются природные условия региона, рассматриваются законы экологии и фенологические изменения природы. Урок окружающего мира посвящается определенному вопросу программы, т. е. представляет собой нечто законченное целое, но в то же время каждый урок является лишь частью курса, становится продолжением предшествующих уроков и опорой для последующих.

В соответствии с требованиями ФГОС НОО [1] урок по предмету «Окружающий мир» должен быть деятельностным, т. е. знания учащиеся должны получать не в готовом виде, а самостоятельно их приобретать в различных способах деятельности. Данное требование не отрицает использование репродуктивных методов обучения (рассказ, беседа, демонстрация фильма и т. д.), но они не должны быть единственными, а применяться могут в случае сложности изучаемой темы или невозможности использования продуктивных методов по изучаемой теме (лабораторный опыт, эксперимент, наблюдение природы, распознавание, дискуссия, моделирование, проектирование).

При выполнении конспекта урока учитель прежде всего разрабатывает цель и задачи урока. Данный вопрос является дискуссионным, в современной начальной школе существует несколько вариантов определения цели и задач урока, поэтому со студентами желательно провести дискуссию по этой проблеме, прежде чем они будут писать свой первый конспект урока по окружающему миру. Предлагаем несколько дискуссионных утверждений по данной проблеме.

Так, довольно распространенным вариантом является подмена слова «цели» на слово «задачи» и наоборот. Например, в поурочных планах по учебному курсу «Мир вокруг нас» А. А. Плешакова [2] и методическом пособии к учебному курсу «Окружающий мир» О. Н. Федотовой, Г. В. Трафимовой и С. А. Трафимова [3] разработаны только задачи урока, но не указана его цель, а в методических рекомендациях по курсу «Мир и человек» А. А. Вахрушева [4] приводятся только цели урока. Изучение обозначенных в методических пособиях целей и задач приводит к мысли, что авторы их считают синонимами и поэтому записывают идентично, хотя на самом деле названные цели являются не чем иным, как триедиными дидактическими задачами урока - развивающими, обучающими и воспитательными.

Е. В. Григорьева [5] в учебном пособии для студентов педагогических вузов также не разделяет термины «цель» и «задачи», называя обучающие, развивающие и воспитательные дидактические иели, но выделяет учебную задачу, которая сообщается учащимся в начале урока с целью ее выполнения и анализа результатов в конце урока.

А. В. Миронов в статье «Как определить цели урока» [6] выделяет семь существующих вариантов определения целей урока, отождествляя их с задачами урока: 1) цели в уроке не обозначены; 2) цели в виде формирования знаний; 3) цели в виде формирования знаний и умений; 4) цели (задачи) обучения, воспитания и развития, исходя из структуры образовательного процесса; 5) цели в виде формирования предметных и метапредметных результатов; 6) формирование планируемых результатов обучения в виде осваиваемых знаний и умений; 7) цели (задачи) урока и планируемые результаты. Далее автор дает подробную характеристику восьмому варианту определения целевого компонента урока, позволяющего привязать урок к планируемому результату: цели как формируемые предметные и метапредметные умения, а также планируемые достижения в виде знаний и умений. Цели урока А. В. Миронов разбивает на две части - предметные умения (их необходимо взять из «Планируемых результатов начального общего образования» [7] в соответствии с темой урока) и метапредметные умения (называются универсальные учебные действия, не более одноготрех); а планируемые достижения автор представляет как результаты совместной деятель- 
ности учителя и учащихся и делит их на две части: знания (формируемые на данном уроке представления и понятия), умения (формируемые предметные умения). Цели урока А. В. Миронов называет «целями учителя», которые не сообщаются школьникам, а планируемые достижения - «целями деятельности», которые сообщаются учащимся.

Выделенные способы целеполагания урока являются, по нашему мнению, довольно запутанными и спорными, поэтому после их обсуждения студентам предлагается вариант определения цели и задач урока, разработанный методистами-биологами (Н. М. Верзилин, В. М. Корсунская, А. Н. Мягкова, В. М. Пакулова, Д. И. Трайтак и др.), который достаточно точен, понятен и полностью соответствует требованиям ФГОС НОО к уроку.

Ученые-методисты утверждают, что дидактическая цель урока должна быть одна, выражена отглагольным существительным (формирование, повторение, обобщение) и определяться по типу урока [8].

Проблема типологии урока окружающего мира также является дискуссионной, поэтому со студентами следует повторить и обсудить несколько классификаций типов урока.

1. По ведущей дидактической цели:

- В. М. Пакулова выделяет вводный, комбинированный, предметный, обобщающий уроки [8];

- 3. А. Клепинина и Г. Н. Аквилева различают вводный, комбинированный, урок-экскурсия, предметный, обобщающий уроки [9];

- Е. Ф. Козина и Е. Н. Степанян рассматривают вводный, комбинированный, обобщающий, контрольный, предметный уроки, урок формирования умений и навыков, урок объяснительного чтения (для системы Л. В. Занкова) [10].

2. По содержанию: экологические, астрономические, биологические, географические, фенологические и другие уроки [10].

3. По ведущему методу обучения: урок-беседа, урок-игра, киноурок, лабораторный урок (И. Н. Казанцев [11]), хотя часть ученых называют данные уроки «видами уроков» (В. М. Пакулова [8], Д. И. Трайтак [12]), или «нестандартными уроками» (И. П. Подласый $[13$, с. 384]), или «модификацией основных типов уроков» (Г. Н. Аквилева, 3. А. Клепинина $[9$, c. 212]).

4. На основе деятельностного метода [1]: Л. Г. Петерсон выделяет урок «открытия» нового знания, урок рефлексии, урок общеметодологической направленности, урок развивающего контроля [14].

5. На основе метода решения учебных задач: Д. Б. Эльконин и В. В. Давыдов рассматривают урок постановки учебной задачи, урок моделирования (конструирования) понятия, урок конкретизации понятия, урок контроля, урок оценки [15].

6. На основе построения образовательных отношений между учителем и учашимися: С. И. Поздеева различает урок-задание, урок-проблематизацию, урок-диалог [16].

Исходя из требований к современному уроку окружающего мира, ни одна из классификаций не является полной, поэтому студентам предлагается составить «собственную» типологию уроков окружающего мира и объяснить ее. Предлагаем классификацию типов урока, составленную группой студентов во время практического занятия:

- Классификация: вводный, урок изучения нового материала, комбинированный, предметный, обобщающий, урок-экскурсия.

- Объяснение: введение в типологию урока изучения нового материала связано с тем, что после обобщающего урока, на котором нет этапа «домашнее задание», не проводится, как правило, комбинированный урок, так как этап «проверка домашнего задания» не предполагается. Принять контрольный урок в типологию также не представляется возможным, 
поскольку традиционно контрольная работа на уроках окружающего мира не должна превышать 25 минут. Урок объяснительного чтения также нежелателен в преподавании окружающего мира, так как, во-первых, этот предмет, начиная с момента своего возникновения (1786 г.), имел практическую направленность, а во-вторых, чтение и пересказ текста в течение всего урока не могут быть способом реализации системно-деятельностного подхода к обучению, предусмотренного ФГОС НОО [1].

После выделения типа урока студент учится определять его цель. Например, цель вводного урока: формирование у учащихся общих представлений об учебном предмете (разделе), который им предстоит изучать. Цель комбинированного урока: обобщение и систематизация имеющихся знаний, приобретение новых знаний, умений и навыков. Цель обобщающего урока: систематизация знаний, полученных при изучении всего раздела (курса), закрепление его наиболее важных положений. Цель предметного урока: получение учащимися знаний самостоятельно в ходе непосредственной работы с предметами живой и неживой природы. Цель урока-экскурсии: получение учащимися знаний самостоятельно в ходе непосредственных наблюдений природы.

Далее студенты узнают, что дидактические задачи урока определяются по его теме, разрабатываются учителем, детям не сообщаются и являются триедиными (обучающие, развивающие, воспитательные). При формулировке дидактических задач урока используются глаголы: сформировать, изучить, закрепить, повторить, систематизировать, обеспечить, способствовать формированию умения, научить и т. д.

Задачи урока, исходя из его темы, должны быть конкретными, понятными, проверяемыми, достижимыми, формулируемыми. Часто начинающий учитель пишет задачи в общем плане: «сформировать монологическую речь», «воспитать экологическую культуру», «сформировать умение работать с контурной картой». Но, во-первых, за один урок подобная задача не решается, во-вторых, она не показывает способ ее реализации на уроке по конкретной теме. Кроме того, нередки ситуации, когда «красиво» проведенное занятие не решает никаких задач, то есть является процессом ради процесса, поэтому правильно поставленные задачи помогают учителю видеть предполагаемый результат конкретного урока и проверить его выполнение.

Обучающие задачи урока по курсу «Окружающий мир» должны содержать следующие элементы: формирование конкретного понятия или представления по данной теме (не более пяти за один урок); развитие специального и (или) общеучебного умения (умений); формирование умения устанавливать взаимосвязи между элементами природы, изучаемыми по данной теме.

К общеучебным умениям относятся: работа с учебником и дополнительной литературой; пересказ текста и составление доклада-сообщения; выполнение письменных работ; работа по плану; работа с таблицами, картинами, схемами; постановка проблемы и ее решение; работа на доске; постановка и выполнение учебной задачи; умение общаться с другими людьми.

К специальным умениям по окружающему миру можно отнести следующие: проведение и фиксация результатов наблюдений и опытов; ведение дневника и календаря наблюдений природы; пользование приборами (термометр, гигрометр, флюгер, компас, снегомерная рейка, гномон, теллурий) и моделями (муляж, модель, макет); ориентирование во времени и пространстве; чтение и понимание карты и плана местности; работа с натуральными пособиями (гербарий, коллекция, препарат, чучело); уход за растением и животным; умения охранять и улучшать окружающую среду; соблюдение правил гигиены и здорового образа жизни; умение вести себя дома, в школе, общественном месте. 
После выхода ФГОС НОО в 2009 г. многие из названных умений были названы универсальными учебными действиями (УУД) как способность самостоятельно использовать приобретенный учебный опыт в любом виде деятельности, с которой школьник встречается в жизни [17]. Студент при выполнении конспекта урока выбирает одно-три УУД, которые возможно формировать по данной теме.

Развивающие и воспитательные задачи урока записываются будущим учителем с указанием конкретных способов реализации в данной теме, но поскольку развитие и воспитание ребенка происходят постепенно, то желательно использовать слова «создать (обеспечить) условия для развития (воспитания)...», «способствовать развитию (воспитанию)...». При такой формулировке при подведении итогов урока можно проверить применение приемов, создающих условия по формированию черт личности младшего школьника.

С будущими учителями начальных классов следует подробно разобрать теорию и практику реализации учебной задачи урока. Учебная задача урока разрабатывается детьми (иногда учителем) и для учащихся является мотивацией познавательной деятельности на предстоящем уроке. Теория учебной задачи была предложена и разработана в системах развивающего обучения Д. Б. Эльконина - В. В. Давыдова и Л. В. Занкова, а после выхода ФГОС НОО она является обязательной при выполнении конспекта урока по любому учебно-методическому комплекту. Учебная задача является целью урока, личностно значимой для учащегося, и строится, как правило, в процессе постановки проблемной ситуации в начале урока, подводящей школьников к осознанию противоречия «известно/неизвестно» и выдвижению предположений о решении главной проблемы урока. При этом учителю важно уметь вовремя «подбросить» школьникам вопрос-провокацию, вопрос-ловушку, которые не имеют прямого ответа и вызывают у школьников удивление, предположения, т. е. заставляют учащихся думать. Студентам предлагается один из вариантов постановки учебной задачи:

- Учитель: «Ребята, мы узнали, что насекомые - это животные, у которых 3 части тела, 6 ног, 2 усика. Тогда правильно ли называть клеща насекомым?»

В основном все дети соглашаются, что правильно. Но учитель показывает фотографию клеща и часть детей с удивлением замечают, что это животное отличается от насекомого.

- Учитель: «Тогда чему будет посвящен наш урок сегодня?»

- Учащиеся: «Узнать, к какой группе относится клещ?»

После постановки учебной задачи дети вступают в диалог, в процессе метода распознавания сравнивают коллекции насекомого и клеща, подсчитывают его части тела и конечности (8 ног, нет усов, а частей тела 2), сравнивают клеща с другими животными. Постепенно диалог-спор и наблюдение подводят учащихся к новому понятию «паукообразные (пауки)».

Затем будущие учителя в творческих группах сами разрабатывают учебные задачи к различным темам урока по предмету «Окружающий мир». Далее делается вывод о том, что в зависимости от содержания урока, учителем устанавливается его тип, на основе которого выдвигается его дидактическая цель и структура. Cmруктура урока - это совокупность его частей, называемых «этапами урока», которые обеспечивают целостность и законченность урока [8-10]. Со студентами необходимо рассмотреть традиционную структуру урока, разработанную Я. А. Коменским: 1) организационный момент; 2) проверка домашнего задания; 3) изучение нового материала; 4) закрепление; 5) домашнее задание; 6) итог урока в виде оценивания деятельности учащихся.

Далее следует выделить и назвать структурные элементы урока в соответствии со стандартом [18]: 1) организация класса (мотивирование на учебную деятельность); 2) ак- 
туализация знаний (если новая тема связана с предыдущей темой) или проверка домашнего задания (если новая тема не связана с предыдущей темой урока); 3) целеполагание (постановка проблемы/учебной задачи); 4) открытие нового знания (поиск способов решения проблемы, решение проблемы, коррекция); 5) закрепление (самоанализ и самоконтроль); 6) включение нового знания в систему имеющихся знаний (самостоятельная практическая работа школьников по использованию полученных знаний); 7) систематизация знаний; 8) объяснение домашнего задания; 9) рефлексия учебной деятельности (итог урока, оценивание). Затем студенты разрабатывают триединые дидактические задачи и учебную задачу в зависимости от темы урока.

Одним из самых распространенных типов урока окружающего мира является комбинированныци, поэтому будущему учителю желательно начинать выполнение конспектов с написания данного типа урока.

Тему урока следует писать конкретно и кратко, в соответствии с учебником (программой). При составлении конспекта урока нужно помнить, что его структурные элементы динамичны и зависят от типа урока. Например, на вводных уроках не предусмотрена проверка домашнего задания, а на обобщающем уроке не может быть этапа изучения нового материала. На комбинированных уроках, как правило, имеют место все его элементы, но в тех случаях, когда содержание нового материала сложное и объемное, учитель разбивает его на логические части и после объяснения каждой порции нового материала сразу проводит закрепление учебного материала, т. е. закрепление осуществляется параллельно с изучение нового материала. Домашнее задание не обязательно называть в конце урока, это можно сделать в середине и даже в начале урока.

В конспекте урока подробно раскрываются методы и приемы, используемые на каждом его этапе. Начинающему учителю, особенно студенту-практиканту, следует составлять подробный конспект урока, а с накоплением педагогического опыта учитель переходит на составление плана урока. Оформление конспекта урока различно: в виде таблицы, в виде технологической карты, в виде последовательного описания каждого этапа урока. Далее студентам предлагаются различно оформленные конспекты урока окружающего мира, которые ими анализируются, обсуждаются, сканируются. Предлагаем для иллюстрации конспект одного из уроков.

\section{Тема урока: "Органы чувств"}

Тип урока: урок-диалог [16].

Цель урока: Реализация открытого совместного действия учителя и учащихся на основе субъект-субъектного взаимодействия.

Задачи: 1) формировать понятие «органы чувств», представление об их строении и функциях; 2) формировать навыки здорового образа жизни на основе изучения санитарногигиенических правил; 3) воспитывать ценностное отношение к своему здоровью; 4) развивать диалогическую речь, наблюдательность и воображение; 5) продолжить развитие умения работать в группах.

Формируемые УУД: личностные: формирование осознанности и обоснованности самооценки; познавательныл: формирование умения видеть и решать проблемную ситуацию; регулятивные: формирование умения планировать свою деятельность; коммуникативные: формирование умения работать группами, совместно договариваться о правилах поведения и общения в группе и следовать им, принимать и понимать различные точки зрения.

Оборудование: презентация «Органы чувств», тексты и схематичные рисунки органов чувств для пяти групп. 
Ход урока

\section{1. Организация класса.}

Учащиеся рассаживаются по группам (по пять человек). Учитель предлагает взяться за руки ребятам каждой группы, улыбнуться друг другу, чтобы поделиться хорошим настроением и почувствовать поддержку товарищей.

2. Мотивация учебной деятельности. Определение темы и учебной задачи урока.

Метод: разгадывание кроссворда. Прием: работа в парах.

Учитель: Давайте поработаем парами. У каждой пары на столе лежит кроссворд. Ваша задача: вместе ответить на занимательные вопросы и вписать в клетки кроссворда словаотгадки:

1. Какой орган у зверей, как правило, на макушке, а у человека - ниже глаз? (ухо). 2. Какой орган у человека не растет после рождения, а остается одинаковым всю его жизнь? (глаз). 3. Какой орган человеческого организма самый большой? (кожа). 4. Какая часть лица человека самая выступающая? (нос). 5. Какой орган человека считается самым гибким и подвижным? (язык).

Учитель: Посмотрите на слайд 1 и проверьте правильность заполнения кроссворда (на экране слайд 1).

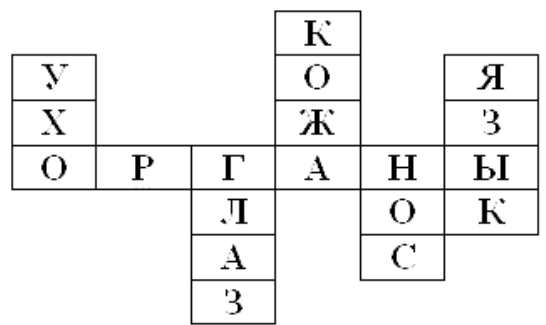

Учитель: Свою работу вам предстоит оценить самостоятельно, а поможет вам «Светофор» (слайд 2). Выберите нужный цвет для оценки работы своей пары: 1. Зеленый - работа выполнена без ошибок. 2. Желтый - в работе есть неверные ответы. 3. Красный - работа не выполнена.

Учитель: Какое ключевое слово у вас получилось при решении кроссворда? (Органы). Подумайте, о каких органах человека сегодня пойдет речь? Попробуйте сформулировать тему урока (Слайд 3: Тема: «Органы чувств»).

Учитель: Попробуйте определить, что вы уже знаете об органах чувств, а что хотите узнать. Для этого заполним таблицу (слайд 3):

\section{Что мы знаем?}

- Названия органов чувств.

- Какую функцию выполняет каждый орган чувств.
Что хотим узнать?

- Как работает каждый орган чувств?

- Как сохранять здоровье каждого органа чувств? чувств?

- Можно ли выделить главный орган

\section{3. Погружение в совместную деятельность.}

Метод: беседа.

Учитель: Чтобы ответить на поставленные вопросы, нам необходимо разделиться на пять групп по четыре человека и провести совместное исследование.

Учитель: Но прежде назовите правила работы в группе (слайд 4):

1. Прочитай внимательно задание.

2. Обдумай поставленную проблему.

3. Обсуди свои предположения с товарищами по группе. 
4. Решите поставленную проблему.

Учитель: Каждой группе предлагается план работы, текст, схематичный рисунок какого-либо органа чувств. Задача группы: в совместном обсуждении выполнить весь план работы и выступить перед классом.

План работы в группе (слайд 5).

1. Прочитайте текст, рассмотрите рисунок.

2. Составьте рассказ по плану: название органа чувств, выполняемые функции, строение органа; заполните таблицу.

3. Составьте памятку о гигиене органа чувств: «Это полезно знать».

4. Совместное открытие знаний.

4.1. Изучение нового материала. Метод: беседа-диалог. Приемы: работа в группе, использование схематичных рисунков.

Задания для групп: учащимся предлагается текст (1-я группа - «Глаза», 2-я группа «Язык», 3-я группа - «Нос», 4-я группа - «Уши», 5-я группа - «Кожа»), из которого они должны выбрать информацию для устного выступления перед классом, а предлагаемая схема органа чувств (слайды 6-10) обсуждается в группе и затем используется в процессе сообщения.

4.2. Обмен информацией. Метод: доклад-сообщение, прием: использование схематичного рисунка на слайде.

Каждая группа проводит презентацию своего органа чувств в виде доклада-сообщения и показа схематичного рисунка. После докладов-сообщений 1-й и 4-й групп учитель проводит физкультминутки: 1) «Гимнастика для глаз»; 2) «Разминка для ушных раковин».

\section{5. Закрепление учебного материала.}

5.1. Метод: беседа.

Учитель: В начале урока мы поставили учебную задачу, давайте вернемся к ней (слайд 3) и подумаем, решили ли мы ее.

- Как работает орган обоняния?

- Повторите, как работает орган вкуса?

- Расскажите, как работает орган слуха?

- Какой орган помогает нам видеть?

- Как человек определяет твердый предмет или мягкий?

5.2. Метод: дискуссия.

Учитель: Давайте обсудим проблему «Можно ли выделить главный орган чувств?».

Учитель: Итак, вы думаете, что все органы чувств одинаково важны, а ученые утверждают, что «не глаз видит, не нос ощущает, не ухо слышит, а мозг». Попробуйте сообща разобраться и в этой проблеме.

\section{6. Рефлексия.}

Метод: занимательное упражнение «Дело в иляпе».

Учитель включает музыку и передает шляпу в руки детям. Учащиеся передают шляпу друг другу, учитель через несколько секунд периодически выключает музыку. Тот школьник, у которого в руках осталась шляпа, делится впечатлением об уроке, анализирует работу своей группы. Завершает упражнение учитель, рассказывая о собственных впечатлениях об уроке.

\section{7. Объяснение домашнего задания.}

Прочитать текст в учебнике на с. 126-128 [19], ответить на вопросы рубрики «Проверь себя».

После изучения различных по оформлению конспектов урока студентам предлагается задание для внеаудиторной самостоятельной работы. 
Пункт 3. Задания для самостоятельной работы студентов. Составить конспект комбинированного урока по одной из тем окружающего мира. С этой целью: 1) познакомиться с программой, прочитать материал учебника, выделить систему понятий урока и формируемых УУД; 2) определить тип урока; 3) разработать цель, дидактические и учебные задачи урока; 4) выделить структурные компоненты урока; 5) определить последовательность формирования понятий (представлений); 6) выбрать методы и приемы, соответствующие понятиям (представлениям); 7) продумать методику применения средств наглядности; 8) разработать способы активизации учебной деятельности; 9) разработать содержание рассказов, вопросы бесед; 10) разработать схемы, рисунки, модели; 11) составить при необходимости инструкции к проведению опытов и наблюдений природы; 12) разработать содержание и способы организации физкультминутки, запланировать время ее проведения; $13)$ продумать домашнее задание; 14) написать подробный конспект урока.

На конкретном примере работы студента при выполнении конспекта урока окружающего мира мы показали, как органическое соединение теоретических знаний и практических умений помогает будущему учителю в самостоятельной внеаудиторной подготовке к созданию целостного произведения - конспекта урока - в рамках изучения любой методической дисциплины.

\section{Список литературы}

1. Федеральный государственный образовательный стандарт начального общего образования. М.: Просвещение, 2011. 33 с.

2. Мир вокруг нас. 2 класс: поурочные планы по учебнику А. А. Плешакова / авт.-сост. О. Г. Муковникова. Волгоград: Учитель, 2009. 152 с.

3. Федотова О. Н., Трафимова Г. В., Трафимов С. А. Окружающий мир. 1 класс: метод. пособие. М.: Академкнига / Учебник, 2014. 97 с.

4. Барышева Ю. Я., Вахрушев А. А., Раутиан А. С. Я и мир вокруг. 1 класс: метод. рекомендации для учителя по курсу окружающего мира «Мир и человек». М.: Баласс, 2007. 128 с.

5. Григорьева Е. В. Методика преподавания естествознания в начальной школе: учеб. пособие для студ. пед. вузов. Челябинск: ЧГПУ, 2015. 283 с.

6. Миронов А. В. Как определить цели урока // Начальная школа. 2016. № 5. С. 84-90.

7. Планируемые результаты начального общего образования / под ред. Г. С. Ковалевой, О. Б. Логиновой. М.: Просвещение, 2009. 120 с.

8. Пакулова В. М., Кузнецова В. И. Методика преподавания природоведения: учеб. пособие для студ. пед. институтов. М.: Просвещение, 1990. 192 с.

9. Клепинина 3. А., Аквилева Г. Н. Методика преподавания естествознания в начальной школе: учеб. пособие для студ. пед. вузов. М.: Академия, 2008. 288 с.

10. Козина Е. Ф., Степанян Е. Н. Методика преподавания естествознания: учеб. пособие для студ. высш. пед. учеб. заведений. М.: Академия, 2004. 496 с.

11. Урок в начальной школе: из опыта учителей / под ред. И. Н. Казанцева. М.: АПН РСФСР. Ин-т теории и истории педагогики, 1951. 223 с.

12. Трайтак Д. И. Проблемы методики обучения биологии: Труды действительных членов Международной академии наук педагогического образования. М.: Мнемозина, 2002. 304 с.

13. Подласый И. П. Педагогика: учеб. для студ. высш. пед. учеб. заведений. М.: Просвещение: Гуманит. изд. центр ВЛАДОС, 1996. 432 с.

14. Петерсон Л. Г. Деятельностный метод обучения: образовательная система «Школа 2000...» // Построение непрерывной сферы образования. М.: АПКиППРО: УМЦ «Школа 2000...», 2007. 448 с.

15. Воронцов А. Б. Практика развивающего обучения по системе Д. Б. Эльконина - В. В. Давыдова // Из опыта работы ЭУК «Школа развития». М.: Центр «Развитие личности», 1998. 360 с.

16. Поздеева С. И. Типология уроков в концепции педагогики совместной деятельности // Научно-педагогическое обозрение (Pedagogical Review). 2016. № 3 (13). С. 36-41. 
17. Асмолов А. Г. Как проектировать универсальные учебные действия в начальной школе. От действия к мысли. М.: Просвещение, 2012. 128 с.

18. Современные технологии проведения урока в начальной школе с учетом требований ФГОС: метод. пособие / под ред. Н. Н. Деменевой. М.: АРКТИ, 2015. 152 с.

19. Плешаков А. А. Окружающий мир. 3 класс: учеб. для общеобразоват. организаций: в 2 ч. М.: Просвещение, 2015. Ч. 1. $175 \mathrm{c}$

Кропочева Татьяна Борисовна, доктор педагогических наук, профессор, Новокузнецкий институт (филиал) Кемеровского государственного университета (ул. Циолковского, 23, Новокузнецк, Россия, 654041). E-mail: krtb@yandex.ru

Налимова Татьяна Анатольевна, кандидат педагогических наук, доцент, Новокузнецкий институт (филиал) Кемеровского государственного университета (ул. Циолковского, 23, Новокузнецк, Россия, 654041). E-mail: nalimova7@rambler.ru

Синева Мария Викторовна, кандидат педагогических наук, доцент, Новокузнецкий институт (филиал) Кемеровского государственного университета (ул. Циолковского, 23, Новокузнецк, Россия, 654041). E-mail: cropocheva87@yandex.ru

Материал поступил в редакиию 13.01.2020.

DOI 10.23951/2307-6127-2020-2-9-22

\section{PREPARING THE ELEMENTARY SCHOOL TEACHER-TO-BE FOR MAKING OF THE LESSON SYNOPSIS}

\section{T. B. Kropocheva, T. A. Nalimova, M. V. Sineva}

Novokuznetsk Institute (Branch) of Kemerovo State University, Novokuznetsk, Russian Federation

An analysis of scientific and methodological literature allowed us to conclude that there has been an increase in scientific publications on the problem of training of the elementary school teachers-to-be. However, many issues related to the preparation of the teacher for organizing and conducting a lesson according to the Federal Educational Standards for Elementary General Education (FES-EGE) are debatable and produce drawbacks in the methodological preparation of the teacher-to-be. These drawbacks determined the study problem: how to prepare the elementary school teacher-to-be for the making of the synopsis of the lesson? The objective of the study is to reveal and substantiate the methodology of the preparation of the elementary school teacher-to-be for the making of the synopsis of the lesson. The theoretical relevance of this study is that it concretizes the essence and content of the preparation of the teacher-to-be for the making of the synopsis of the lesson and theoretically substantiates the methodology of the preparation of the teacher-to-be for the making of the lesson synopsis. The practical relevance is that it has developed the organization of independent work by the teacher-to-be regarding his or her preparation for the making of the lesson synopsis according to FES-EGE. Providing the good training of specialists requires not only observing the governmental educational standards that determine minimum requirements to the content and level of the training but also a more effective control of mastering the content of education by the students including independent work that is now a significant part compared to classroom lessons. The theoretical theses of the methodology of preparation of the teacher-to-be for making of the lesson synopsis are illustrated by a synopsis performed in accordance with the modern typology and structure of the lesson described in FES-EGE. The preparation of the 
elementary school teacher-to-be for making of the synopsis of the lesson is defined as a process including the formation of a system of knowledge (the typology, goal setting and the structuring of the lesson), skills (the skills of determining the type, the goal, the didactic tasks, the universal teaching actions, the structure of the lesson and the methods of teaching) and personal and professional qualities (creative imagination and pedagogical improvisation) providing the effective organization of the lesson according to the requirements of FES-EGE.

Keywords: preparation of the teacher-to-be, synopsis of the lesson, objective, typology, structure of the lesson.

\section{References}

1. Federal'nyy gosudarstvennyy obrazovatel'nyy standart nachal'nogo obshchego obrazovaniya [Federal state educational standard of primary General education]. Moscow, Prosveshcheniye Publ., 2011. 33 p. (in Russian).

2. Mir vokrug nas. 2 klass: pourochnyye plany po uchebniku A. A. Pleshakova. Avt.-sost. O. G. Mukovnikova [World around us. Class 2: lesson plans for the textbook A. A. Pleshakov. Author-compiler O. G. Mukovnikova]. Volgograd, Uchitel' Publ., 2009. 152 p. (in Russian).

3. Fedotova O. N., Trafimova G. V., Trafimov S. A. Okruzhayushchiy mir. 1 klass: metodicheskoye posobiye [The world. Class 1: methodical manual]. Moscow, Akademkniga / Uchebnik Publ., 2014. 97 p. (in Russian).

4. Barysheva Yu. Ya., Vakhrushev A. A., Rautian A. S. Ya i mir vokrug. 1 klass: metodicheskiye rekomendatsii dlya uchitelya po kursu okruzhayushchego mira "Mir i chelovek" [I and the world around. Class 1: teachers on the course of the environment "The World and Man"]. Moscow, Balass Publ., 2007. 128 p. (in Russian).

5. Grigor'yeva E. V. Metodika prepodavaniya yestestvoznaniya v nachal'noy shkole: uchebnoye posobiye dlya studentov pedagogicheskikh vuzov [Methods of teaching natural science in primary school: textbook for students of pedagogical universities]. Chelyabinsk, CHSPU Publ., 2015. 283 p. (in Russian).

6. Mironov A. V. Kak opredelit' tseli uroka [How to determine the purpose of the lesson]. Nachal'naya shkola, 2016, no. 5, pp. 84-90 (in Russian).

7. Planiruyemyye rezul'taty nachal'nogo obshchego obrazovaniya. Pod red. G. S. Kovalevoy, O. B. Loginovoy [Planned results of primary General education. Ed. G. S. Kovaleva, O. B. Loginova]. Moscow, Prosveshcheniye Publ., 2009. 120 p. (in Russian).

8. Pakulova V. M., Kuznetsova V. I. Metodika prepodavaniya prirodovedeniya: uchebnoye posobiye dlya studentov pedagogicheskikh institutov [Methods of teaching natural science: study guide for students of pedagogical institutes]. Moscow, Prosveshcheniye Publ., 1990. 192 p. (in Russian).

9. Klepinina Z. A., Akvileva G. N. Metodika prepodavaniya yestestvoznaniya v nachal'noy shkole: uchebnoye posobiye dlya studentov pedagogicheskikh vuzov [Methods of teaching natural science in primary school: textbook for students of higher educational institutions]. Moscow, Akademiya Publ., 2008. 288 p. (in Russian).

10. Kozina E. F., Stepanyan E. N. Metodika prepodavaniya yestestvoznaniya: uchebnoye posobiye dlya studentov vysshikh pedagogicheskikh uchebnykh zavedeniy [Methods of teaching natural sciences: textbook for students of higher pedagogical educational institution]. Moscow, Akademiya Publ., 2004. 496 p. (in Russian).

11. Urok v nachal'noy shkole: iz opyta uchiteley. Pod red. I. N. Kazantseva [Lesson in primary school: from the experience of teachers. Ed. I. N. Kazantsev]. Moscow, APN RSFSR. In-t teorii i istorii pedagogiki Publ., 1951. 223 p. (in Russian).

12. Traytak D. I. Problemy metodiki obucheniya biologii: Trudy deystvitel'nykh chlenov Mezhdunarodnoy akademii nauk pedagogicheskogo obrazovaniya [Problems of methodology of teaching biology: proceedings of the valid members of the International science Academy of pedagogical education]. Moscow, Mnemozina Publ., 2002. 304 p. (in Russian).

13. Podlasyy I. P. Pedagogika: uchebnik dlya studentov vysshikh pedagogicheskikh uchebnykh zavedeniy [Pedagogics: textbook for students of higher ped. textbook. institutions]. Moscow, Prosveshcheniye: Gumanit. izd. tsentr VLADOS Publ., 1996. 432 p. (in Russian).

14. Peterson L. G. Deyatel'nostnyy metod obucheniya: obrazovatel'naya sistema "Shkola 2000...". Postroyeniye nepreryvnoy sfery obrazovaniya [Activity method of training: educational system "School 2000..." Building a continuous sphere of education]. Moscow, APKiPPRO: UMTS «Shkola 2000...» Publ., 2007. 448 p. (in Russian). 
15. Vorontsov A. B. Praktika razvivayushchego obucheniya po sisteme D.B. El'konina - V.V. Davydova. Iz opyta raboty EUK "Shkola razvitiya" [Practice of developing training on the system of D. B. Elkonin - V. V. Davydov. From the experience of EUK "School of development”]. Moscow, Tsentr «Razvitiye lichnosti» Publ., 1998. 360 p. (in Russian).

16. Pozdeyeva S. I. Tipologiya urokov v kontseptsii pedagogiki sovmestnoy deyatel'nosti [Typology of lessons in the concept of pedagogy of joint activity]. Nauchno-pedagogicheskoye obozreniye-Pedagogical Review, 2016, vol. 3 (13), pp. 36-41 (in Russian).

17. Asmolov A.G. Kak proyektirovat' universal'nyye uchebnyye deystviya v nachal'noy shkole. Ot deystviya $k$ mysli [How to design universal educational actions in primary school. From action to thought]. Moscow, Prosveshcheniye Publ., 2012. 128 p. (in Russian).

18. Sovremennyye tekhnologii provedeniya uroka $v$ nachal'noy shkole s uchetom trebovaniy FGOS: metodicheskoye posobiye. Pod red. N. N. Demenevoy [Modern technologies of conducting a lesson in primary school, taking into account the requirements of the Federal state educational system: methodological guide. Ed. N. N. Demeneva]. Moscow, ARKTI Publ., 2015. 152 p. (in Russian).

19. Pleshakov A. A. Okruzhayushchiy mir. 3 klass: uchebnik dlya obshcheobrazovatel'nych organizatsiy. V 2 chastyah. Chast 1 [The world around us. Class 3: textbook for educational organizations. 2 parts. Patr 1]. Moscow, Prosveshcheniye Publ., 2015. 175 p. (in Russian).

Kropocheva T. B., Novokuznetsk Institute (Branch) of Kemerovo State University (ul. Tsiolkovskogo, 23, Novokuznetsk, Russian Federation, 634061).

E-mail: krtb@yandex.ru

Nalimova T. A., Novokuznetsk Institute (Branch) of Kemerovo State University (ul. Tsiolkovskogo, 23, Novokuznetsk, Russian Federation, 634061).

E-mail: nalimova7@rambler.ru

Sineva M. V., Novokuznetsk Institute (Branch) of Kemerovo State University (ul. Tsiolkovskogo, 23, Novokuznetsk, Russian Federation, 634061).

E-mail: cropocheva87@yandex.ru 